\title{
Tagrinov: coping agroliteration during the covid-19 pandemic in Indonesia
}

\author{
Didu Wahyudi* \\ Indonesian Center for Agricultural Technology Assessment and Development (ICATAD), 16164, \\ Bogor, Indonesia
}

\begin{abstract}
Agroliteration is a group learning space that teaches people how to use technology to be more efficient in their farming activities. The study's goals were to find out: 1) agroliteration in the Agro Innovation Park (Taman Agro Inovasi/Tagrinov) before and during the COVID-19 pandemic, and 2) redesign of Tagrinov agroliteration during the COVID19 pandemic. Tagrinov, located in Bogor, Indonesia, is a showcase of technical advances in the concept of innovative garden utilization from the Indonesian Agency for Agricultural Research and Development of the Ministry of Agriculture. The study makes use of Tagrinov observational data on agroliteration from 2018 to 2020. This finding revealed that Tagrinov's agroliteration participants during the COVID-19 pandemic exhibited the following characteristics:1) technical training participants: government employees (64.84\%), farmer women's group (32.28\%), and students $(2.88 \%), 2)$ education participants: students $(97.25 \%)$, the community $(1.96 \%)$, and members of the Indonesian People's Representative Council $(0.79 \%)$, and 3 ) internship and research activities participants: colleges (100\%). During the COVID-19 pandemic, agroliteration was redesigned to focus on three things: the beginning of independent fundraising through paid services, student participant services via the internet of things (IoT), and non-student participant services via: limiting numbers, maintaining distance, and the imposition of a face mask.
\end{abstract}

\section{Introduction}

The spirit of the Indonesian Agency for Agricultural Research and Development (Balitbang) of the Ministry of Agriculture (Kementan) in conducting research and development of agricultural innovation emphasizes the spirit aspect of science, innovation, and networks [1]. The results of the development of agricultural innovations are aimed at the efficiency of farming activities through the application of technology [2].

The application of farming technology in the community often results in not being maximized, partly due to inadequate public knowledge about agricultural technology tools and the assistance of experts related to technological tools [3]. Thus, a technology demonstration is needed that serves as a model for the dissemination of agricultural innovation and management of agricultural businesses. The establishment and development

\footnotetext{
* Corresponding author: didubbp2tp@yahoo.com
} 
of an innovative agricultural business system that will also serve as a location for internships, training, business incubation, and tourism objects will be the field realization. This activity is carried out simultaneously, which is known as agroliteration.

Agroliteration is a new concept that is gaining popularity. This concept entails agricultural-based economic business activities that generate innovation using knowledge. It's like a technology learning environment. The innovations that result have an impact on increasing the productivity of agricultural business activities, which leads to an increase in profitability. The innovations reach into the learning space where the community relates to information access to open a new paradigm in farming, namely the scale of economic management and the application of advanced, independent, and modern agriculture. Demonstration plots are critical in the agroliteration movement because they unleash a community's creative potential when it has access to information [4].

Farmers' information literacy is critical for farm growth, increasing farm income, promoting agricultural efficiency, and rural development. The goals of this research are to learn about 1) the difficulty farmers have in understanding their needs, sources, and access to agricultural information, and 2) the difficulty farmers have in possessing, synthesizing, and analysing information [5]. The success of increasing the productivity and welfare of farmers will be realized if technology through its multiplier effect on increasing productivity is applied massively by farmers as the main human resources actors.

Agro Innovation Park (Taman Agro Inovasi/Tagrinov) is a showcase of technological innovations from the Indonesian Agency for Agricultural Research and Development of the Ministry of Agriculture, as well as a place for education and learning about the concept of innovative garden utilization. It is in Bogor, Indonesia [6]. Tagrinov's agroliteracy activities include edutourism, technical training, internship and research activities, and technical assistance.

Tagrinov's agroliteracy was visited by 6,186 people between 2018 and 2020. The large number of visitors cannot be separated from the factors that contribute to its attractiveness, which include miniature displays on an overly large $1,200 \mathrm{~m}^{2}$ plot of land, featuring five functions of the yard, agribusiness clinic services, and technical assistance activities (social communities, schools, farmer groups, and others), a comfortable place (there is a coffee corner), and an easy-to-reach location [7].

\section{Literature review}

\subsection{Coping}

Coping is a reaction to the demands of internal and external changes that are problemfocused [8]. Coping is a process that takes place in an environment to overcome obstacles [9]. Efforts to overcome these changes are known as coping strategies. The proponents of this theory are $[10,11]$. They agreed to categorize coping as problem-centered or emotioncentered. The focus on emotion management distinguishes the two. Stuart and Sundeen [10] concentrate on managing negative emotions, whereas Lazarus and Folkman [11] concentrate on positive emotions.

The method of coping chosen is highly dependent on the nature of the problem [12]. In situations where changes can be made constructively, the strategy is problem-focused, whereas in difficult situations, such as the death of a spouse, the strategy is emotionfocused. The success or failure of coping will determine whether the reaction to stress will decrease and whether the fulfillment of $[13,14]$. 


\subsection{Information literacy}

The challenges of information literacy are divided into three stages: an individual's readiness to seek information from various sources, test the accuracy of the information, and apply the information he obtains. At the farmer's level, information literacy is typically obtained through a personal approach from the farmer's group [15].

Today, the acquisition of information literacy is obtained through internet access facilities. This is a challenge for education providers to adjust the curriculum according to the current situation. Teachers must strive for abilities in critical thinking and problem solving, communication and collaboration, creative and innovative thinking, and information and technology literacy [16].

\subsection{Literacy activities during the covid-19 pandemic}

The Indonesian government implemented a policy on bureaucratic service activities, such as adjusting working hours and working from home. Bureaucratic services can be completed online or in person, but the health protocol must be followed. At school, learning activities are carried out at students' homes via various applications, online lectures, online tutoring, and seminars. This policy has encouraged the growth of innovative digital technology practices, which are a key aspect of the implementation of Industry 4.0, provided that the supporting infrastructure is met.

\section{Methodology}

Tagrinov agroliteracy activity data from 2018 to 2020 are used in this study. Its activities range from edutourism, technical training, internship and research activities, and technical assistance. Tagrinov's agroliteracy materials are showing technology, material presentation, discussion, training, and field practice. Data analysis was carried out descriptively on visitor characteristics before and after the pandemic, whereas the Tagrinov agroliteracy redesign was analysed qualitatively.

\section{Results and discussion}

The attraction was successful in enticing people to visit Tagrinov. According to the findings of the visitor satisfaction questionnaire analysis, there are two attractive factors, namely the main and supporting attractions. The main draws are five-yard functions (local wisdom), agribusiness clinic services, technical assistance activities, and display technology: family farming, urban farming, and smart farming. While the supporting attractions include: a space that is neither too large nor too small, a coffee corner, ATM facilities, a large parking area, and an easily accessible location.

The process of enticing the public begins with changing the public's attitude toward public services from rigid and bureaucratic to fun and simple. According to the findings of our study in Tagrinov, the community's initial attitude was caused by a lack of public information about the research office's activities, particularly in the Cimanggu area. The community perceives the area to be populated by serious and rigid employees. It never occurred to the public that they could obtain information about research activities, particularly in the form of public services. Then, in the minds of the public, there is a stigma that the service bureaucracy is overly complicated.

We have broken the stigma by promoting Tagrinov's activities in public places, including large shopping malls. Agro Innovation Fair Exhibition at Botani Square on 30 September 2015-4 October 2015, Exhibition at Takol Park IPB 2015, Launching of Science 
Park and Agricultural Technology Park on 2-4 December 2015, Agro Innovation Fair at Taman Anggrek Mall 2016, and the opening of training results from the Agro Innovation Fair activities were among the events held.

These promotions include introducing service products as well as providing communication and access for the public to seek additional information. In addition, we reduce bureaucracy by providing informal services through social media networks. Finally, we had a result. When the community decided they needed agroliteracy information, they went to Tagrinov. The entire procedure took three years. The promotion occurred in 20152017.

\subsection{Overview of Tagrinov agroliteracy activity}

Tagrinov's agroliteracy is divided into two categories: before and during the Covid-19 pandemic, with 2018-2019 being before Covid-19 and 2020 being during the Covid-19 pandemic.

\subsubsection{Before the Covid-19 Pandemic}

The number of visitors in 2018 reached 2,711 people, while in 2019 , there were 2,843 people. The pattern of visits for 2018 is based on June-December. The peak of the visit occurred in May 2018, which reached 1,035 people, which, at that time, coincided with the Balitbang event held in the Cimanggu area. For the pattern in 2019, the density of the number of visits was almost throughout the month and only stopped/slightly during the fasting month and Eid.

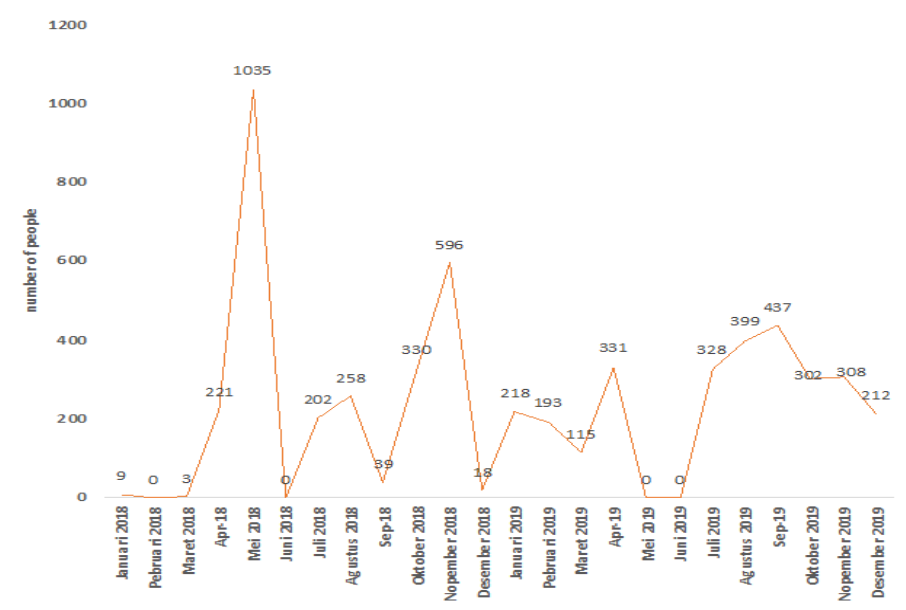

Fig. 1. Visitor count at Tagrinov's agroliteracy 2018-2019

The demand for edutourism dominates Tagrinov's agroliteracy. It is more of a general introduction to Tagrinov's garden displays and innovative technologies. In 2018, two specialized activities dominated: 88 percent of edutourism and the remaining 12 percent of technical training. In 2019, the types of services changed to three specialized activities: 79 percent edutourism, 3 percent internship and research activities, and 18 percent technical training. It demonstrates a 9 percent shift in visitor interest toward a more technical interest in agriculture. 

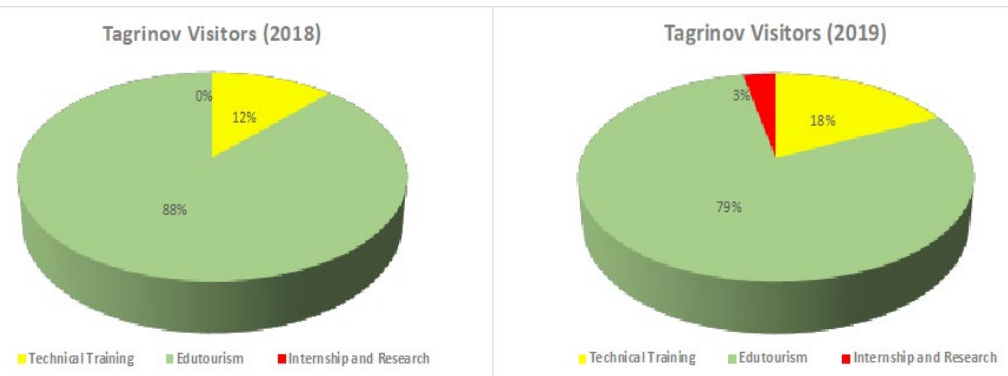

Fig. 2. Visitor interest at Tagrinov's agroliteracy 2018-2019

Beneficiaries of edutourism come from all walks of life. In 2018, 13 groups participated in edutourism, with students (kindergarten, elementary, junior high, high school, and universities) accounting for 45.21 percent of the total of 2,380 participants. This figure was revised in 2019 to 14 edutourism, with students (kindergarten, elementary, junior high, and high school) accounting for $71 \%$ of the total interest of 2,245 people. The Ministry of Agriculture launched a school-entry agriculture program this year, with the goal of bringing agriculture closer to the classroom.

Tagrinov service recipients include: 1) early age groups; 2) middle school age groups; 3) student groups; 4) public groups; (5) agency/service groups; and (6) associations (citizens, families, and alumni). The materials provided are as follows: 1) for the early age group, primary and secondary schools, the topics studied include the introduction of plants and livestock; and 2) for the adult age group, the topics studied include urban agriculture and hydroponic plant cultivation techniques.

\subsubsection{During the Covid-19 pandemic}

The first Covid-19 case in Indonesia was discovered in early March 2020. Tagrinov services in 2020 are being revised because of the impact of Covid-19. It consists of mentoring activities, visits, and the distribution of plant seeds. Technical assistance, garden layouts, FGDs, mentoring Farmer Women's Group activities, mentoring school gardens, strengthening technology displays, exhibitions, and strengthening Village Seed Gardens (Kebun Benih Desa) were among the mentoring activities carried out. Despite limited funds, there is still a high demand for Tagrinov's services. However, due to limited funds, mentoring activities are limited to those in the Jabodetabek area. This considers the remaining resource availability.

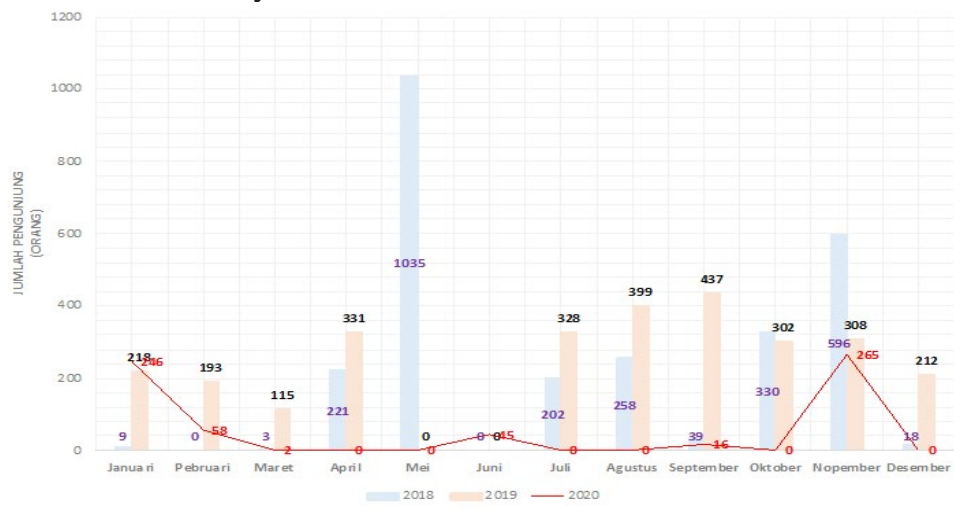

Fig. 3. Visitor count at Tagrinov's agroliteracy 2020 
Tagrinov agroliteracy in 2020, a drop in visitor numbers due to the impact of Covid- 19 . The number of visitors in 2020 reached 632 people. The first Covid-19 case was discovered in early March 2020. The number of visitors in 2020 fell by 77.77 percent compared to 2019. In terms of service type, visits to technical training in 2020 decreased by 31.56 percent from the previous year but increased by 4.83 percent from the previous year.

Edutourism decreased by 88.65 percent in 2019 and 89.29 percent in 2018, while technical training decreased by 67.04 percent in 2019. Since the Covid-19 pandemic, one of the dominant factors in the decrease in public visits to Tagrinov has been the policy of the health protocol.

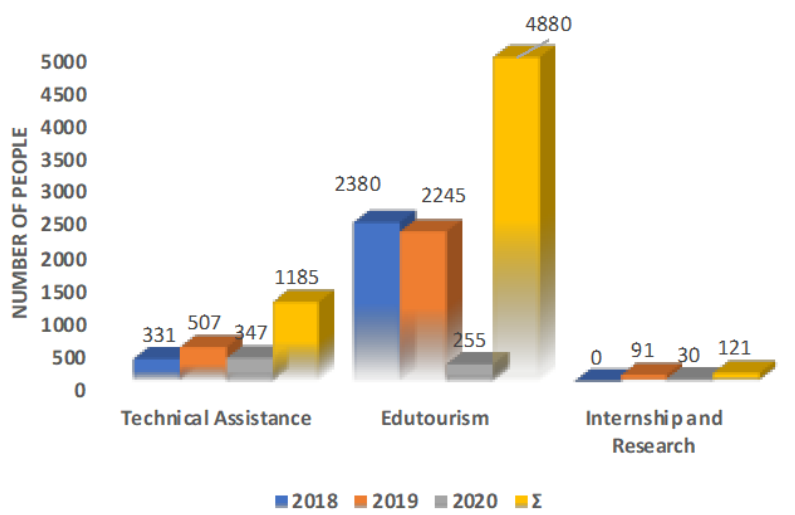

Fig. 4. Visitor interest at Tagrinov's agroliteracy 2020

Tagrinov's agroliteracy traits reflect the nature of the service and the participants' backgrounds. The outcomes are meant to be used as resources to help people cope with agroliteracy. The results are used to better understand the character.

Table 1. Tagrinov's Agroliteracy Performance 2020

\begin{tabular}{|c|c|c|c|c|c|c|c|}
\hline \multirow[b]{2}{*}{ Agroliteracy } & \multicolumn{6}{|c|}{ Background } & \multirow[b]{2}{*}{$\begin{array}{c}\text { Total } \\
\text { (people) }\end{array}$} \\
\hline & Students & Community & $\begin{array}{c}\text { Farmer } \\
\text { Women's } \\
\text { Group }\end{array}$ & $\begin{array}{c}\text { Gov. } \\
\text { Employees }\end{array}$ & $\begin{array}{c}\text { Member of People } \\
\text { Representative } \\
\text { Council }\end{array}$ & Extentionist & \\
\hline \multicolumn{8}{|c|}{ 2018-2019 (before the covid-19 pandemic) } \\
\hline $\begin{array}{l}\text { Technical } \\
\text { Assistance }\end{array}$ & 45 & 224 & 440 & 84 & - & 45 & 838 \\
\hline Edutourism & 2,790 & 1,327 & 115 & 297 & 96 & - & 4,625 \\
\hline $\begin{array}{l}\text { Intership and } \\
\text { Research }\end{array}$ & 91 & - & - & - & - & - & 91 \\
\hline \multicolumn{8}{|c|}{2020 (during the covid-19 pandemic) } \\
\hline $\begin{array}{l}\text { Technical } \\
\text { Assistance }\end{array}$ & 10 & - & 112 & 225 & - & - & 347 \\
\hline Edutourism & 248 & 5 & - & - & 2 & - & 255 \\
\hline $\begin{array}{c}\text { Intership and } \\
\text { Research }\end{array}$ & 30 & - & - & - & - & - & 30 \\
\hline Total (people) & $\begin{array}{c}3,214 \\
(51.9 \%)\end{array}$ & $\begin{array}{c}1,556 \\
(25.1 \%)\end{array}$ & $\begin{array}{c}667 \\
(10.7 \%)\end{array}$ & 606 & 98 & 45 & 6,186 \\
\hline
\end{tabular}

This finding revealed that Tagrinov's agroliteration participants during the COVID-19 pandemic exhibited the following characteristics:1) technical training participants: government employees (64.84\%), farmer women's group (32.28\%), and students $(2.88 \%)$, 2) education participants: students $(97.25 \%)$, the community $(1.96 \%)$, and members of the Indonesian People's Representative Council (0.79\%), and 3) internship and research participants: colleges $(100 \%)$. 
Aside from visits and mentoring activities, one of the services that will be available in 2020 is the distribution of plant seeds to the community. When compared to 2019, the number of plant distributions submitted to visitors/community in 2020 decreased. In terms of diversity, however, plant types will vary in 2020 . There were 4,597 plant polybags and 23 tabulampots distributed to the community in 2019. Meanwhile, 2,889 polybags, 2 tabulampots, 75 pots, 3 seed packs, 4 springkels, 2 orchid display media, and 300 hydroponic netpots were distributed to the community in 2020.

Tagrinov increased its capacity for technology display in 2020 by developing an IoTbased Innovative Garden Land Utilization Technology. This activity is the result of a collaboration with colleges that will intern in Tagrinov in January and February 2020. This activity's synergy is a lesson for Tagrinov's management in the future. It is hoped that students' Internship/Research activities in Tagrinov will be directed toward building/increasing Tagrinov's capacity in accordance with the specific conditions of the location in the coming year.

During the pandemic and while working from home, the community participated in a variety of pandemic-related activities, including gardening. Initially, the selection of these activities was based on seeking entertainment, spending time at home, keeping up with the latest lifestyle trends, and lowering household expenses rather than on need.

Interest in home gardening is expected to rise during the pandemic, owing to the WFH policy that allows people to schedule their activities as they see fit. Many people choose to garden during a pandemic for a variety of reasons. The first reason for gardening is concern about food availability during a pandemic. The lockdown policy disrupts the food supply chain, so its availability must be considered, especially during disasters $[17,18]$. This encourages people to plant food crops such as vegetables, fruits, and spices on their land, even if they cannot meet the needs of all family members.

The second reason for gardening is for recreation [19]. This encourages people to plant not only vegetables, but also plants with aesthetic value, such as ornamental plants. Gardening activities can be performed by all family members, including both parents and children, and can serve as an alternative activity at home during the pandemic.

During the pandemic, food cultivation in urban areas (urban farming) was in high demand in Indonesia. For people who live in urban areas with limited land, vertical, hydroponic, and aquaponic planting techniques are viable options. In addition to providing entertainment, urban farming is expected to generate additional income for the community, particularly for those who have lost their jobs because of the pandemic.

With the explanation above, community visits to Tagrinov should be suspected during activity restrictions because of the community's response in overcoming the Covid-19 pandemic. Tagrinov visitors may be those looking for agricultural technology literacy or those looking for activities during the Covid-19 pandemic. The fact that Tagrinov is a demonstration of food cultivation in urban areas (urban farming), which is in high demand during the pandemic, is reassuring.

\subsection{Redesign of Tagrinov agroliteration during the COVID-19 pandemic}

One of the impacts of the Covid-19 pandemic is how to seek independent funding for Tagrinov's agroliteracy activities so its management activities do not stop. They must pay for agroliteracy services.

These services can respond to the challenges of change brought about by the Covid-19 pandemic. Students, who are among the most frequent users of Tagrinov's agroliteracy, face activity restrictions because of the health protocol's implementation. The traditional face-toface and in-person learning methods have given way to learning through specific applications. 
The application is a tool for channeling student creativity through innovations in assigned tasks. Students must be able to adapt to and benefit from the Revolution 4.0 era of education, which is underpinned by the Covid-19 pandemic, all of which has limited movement and mobility to deal directly with the implementation of the internet of things (IoT).

The internet has become an intermediary in literacy activities in the field of education during the Covid-19 pandemic. Although the process of face-to-face activities and visits can still be carried out, with the policy of limiting numbers, maintaining distance, and the imposition of a face mask. As a result, Tagrinov's agroliteracy services must adapt to the user, specifically by integrating agroliteracy services with technological networks.

\section{Conclusion and recommendation}

Agroliteracy is a learning space for the public to study agriculture based on advanced, independent, and modern concepts. Its goal is to achieve efficiency in farming activities by utilizing technology.

Tagrinov is one of the agroliteracy models whose visitor base is students. During the Covid-19 pandemic, they faced demands for changes both in terms of budgeting and in terms of service. Responding to this is done through coping strategies.

Tagrinov's coping strategy is to focus on problems, with technology serving as an intermediary in literacy activities during the Covid-19 pandemic. Literacy activities during the Covid-19 pandemic provided opportunities for many parties to collaborate in terms of using digital technology and coming up with creative solutions to help students complete their schoolwork and receive agroliteracy services.

\section{References}

1. Badan Penelitian dan Pengembangan Pertanian, Rencana Strategis Badan Penelitian dan Pengembangan Pertanian 2015-2019 Edisi Revisi (Badan Penelitian dan Pengembangan Pertanian, Kementerian Pertanian, Jakarta (ID), 2016)

2. E.Pasandaran, Perspektif kebijakan menuju pertanian masa depan dalam manajemen kebijakan teknologi dan kelembagaan mendukung pertanian modern (IAARD Press, 11-35, 2010)

3. D. Wahyudi, V.W. Hanifah, D. Suryaningtyas, A. Subaidi, L. Hutahean, E. Sirnawati, L. Mailena, A.P.W. Ethika, M. Ramdhani, N.A. Purwatiningsih, W. Siska, and E. Aminah. Pengelolaan taman agro inovasi laporan akhir kegiatan (Balai Besar Pengkajian dan Pengembangan Teknologi Pertanian, Bogor, 2019)

4. M. Siti. J. Konsel. Andi Matappa. 1, 2, 101-107 (2017)

5. A.B. Raya, S.P. Wastutiningsih, P.M. Penggalih, S.P. Sari, D.A. Purwani, JSEP. 10, 1 (2017)

6. D. Wahyudi, M. Ubaidilah, D. Ratnawati, W. Sholihah, T. Tresnawati, Development of mobile-based apps towards smart farming technology in Agro Innovation Park (Tagrinov) Management, in IOP Conf. Series: Earth and Environmental Science 756 (2021)

7. D. Wahyudi, D. Medionovianto, A.P.W. Ethika, Nurhayati, E. Sirnawati, Andriati, M. Ramdhani, Y. Sihombing, N.A. Purwatiningsih, and R. Purnamayani. Pengelolaan taman agro inovasi laporan akhir kegiatan (Balai Besar Pengkajian dan Pengembangan Teknologi Pertanian, Bogor, 2020) 
8. R. Marliani, E. Nasrudin, R. Rahmawati, Z. Ramdani, Regulasi emosi, stres, dan kesejahteraan psikologis: Studi pada ibu work from home dalam menghadapi pandemi COVID-19 (Karya Tulis Ilmiah LP2M UIN SGD Bandung, Jawa Barat, 2020)

9. J.P. Chaplin, Kamus lengkap psikologi. Cetakan Keenam (PT. Raja Grafika Persada, Jakarta, 2002)

10. Stuart, Sundeen, Pocket guide to psyhiatric nursing (ed. 3) (The Mosby Company, Toronto, 1991)

11. R.S. Lazarus, S. Folkman, Stress, appraisal, and coping (McGraw-Hill, Inc. New York, 1984)

12. G.W. Evans, P. Kim, Child. Dev. Perspect. 7, 1, 43-48 (2013)

13. M. Rutter, J. Child Psychol. Psychiatry. 54, 4, 474-487 (2013)

14. B.E. Compas, S.S. Jaser, J.P. Dunbar, K.H. Watson, A.H. Bettis, M.A. Gruhn, E.K. Williams, Australian J. Psychol. 66, 2, 71-81 (2014)

15. N. Indrianti, Pemulihan Industri Pascacovid-19: Perspektif Sustainability, in Prosiding Industrial Engineering Conference (Iec) (2020)

16. A. Ansori, A.F. Sari, J. Lit. Pend. Nusant. 1, 2, 133-148 (2020)

17. C. Walljasper, T. Polansek, Home gardening blooms around the world during coronavirus lockdowns, Routers. Available at: https://www.reuters.com/article/ushealth-coronavirus-gardens/homegardening-blooms-around-the-world-duringcoronavirus-lockdownsidUSKBN2220D3 (2020)

18. S. Jribi, H.B. Ismail, H. Debbabi, Env. Dev. Sustain. 22, 3939-3955, doi: 10.1007/s10668-020-00740-y (2020)

19. G. Ambrose, K. Das, Y. Fan, A. Ramaswami, Landscape and Urban Planning, 198, 103776, doi: 10.1016/j.landurbplan (2020) 